\title{
The Effect of Water Deficit during Early Fruit Development on Olive Fruit Morphogenesis
}

\author{
Hava F. Rapoport ${ }^{1}$ and Giacomo Costagli ${ }^{2}$ \\ Instituto de Agricultura Sostenible, C.S.I.C., P.O. Box 4084, 14080 Cordoba, Spain \\ Riccardo Gucci \\ Dept. di Coltivazione e Difesa delle Specie Legnose, University of Pisa, Via del Borghetto 80, 56124 \\ Pisa, Italy
}

AdDitional INDEX WORDs. Olea europaea, cell number, cell size, endocarp, mesocarp, water potential

\begin{abstract}
Aвstract. Water deficit was applied between 4 and 9 weeks after full bloom by withholding irrigation from 3-year-old Olea europaea L. ('Leccino') plants grown in $2 \mathrm{~L}$ containers in a greenhouse. At 6, 8, and 22 weeks after full bloom (AFB), fruit were sampled for fresh weight and volume determinations, and then fixed for anatomical studies. Structural observations and measurements were performed on transverse sections at the point of widest fruit diameter using image analysis. Water deficit applied between 4 and 9 weeks AFB produced a significant decrease in predawn leaf water potential, which reached minimum values of -3.1 MPa. The applied water deficit reduced fruit fresh weight and volume at 8 and 22 weeks AFB. Fruit transverse area of the water deficit treatment was 50\%, 33\%, and 70\% of the irrigated one at the 6-, 8-, and 22-week sampling dates, respectively. Mesocarp growth occurred for both irrigated and water deficit plants between 8 and 22 weeks AFB. At 22 weeks AFB differences between treatments were significant for mesocarp transverse area, but not for endocarp area. Mesocarp cell size, indicated by area, was significantly different between treatments at 8 and 22 weeks AFB. However, the mesocarp cell number was similar for both treatments at all times, and most mesocarp cells were produced by 6 weeks AFB. The growth of endocarp area showed the greatest shift in timing in response to the early water deficit. Ninety percent of endocarp growth had occurred by 8 weeks AFB in the irrigated treatment, but only $40 \%$ when the deficit irrigation treatment was imposed.
\end{abstract}

The olive (Olea europaea L.) tree is well adapted to arid environments, as it can withstand long periods of drought, high temperature, low humidity and high radiation regimes (Bongi and Palliotti, 1994). Olive trees have been traditionally grown under dryland conditions in the Mediterranean basin. In recent years, irrigation has been shown to increase yield, fruit size, flesh-to-pit ratio and oil content (Goldhamer et al., 1994; Inglese et al., 1996; Lavee et al., 1990; Proietti and Antognozzi, 1996). Therefore, irrigation of olive trees is becoming very popular worldwide.

Because of the scarce water supply in areas where olive trees are usually grown, there is a need to save water or increase water use efficiency. Regulated deficit irrigation (RDI) consists of applying an amount of water less than the evapotranspirative requirement of a crop at selected phenological stages (Mitchell et al., 1986). In deciduous fruit trees there are several reports showing that RDI strategies can effectively save irrigation water, while yield or crop quality are similar or increased with respect to fully irrigated trees (Behboudian and Mills, 1997). Regulated deficit irrigation has only recently been explored for olive trees (Goldhamer et al., 1994).

To optimize RDI management, precise knowledge about the effects of selected periods of drought on the developmental processes that determine final fruit size and crop yield is critical. Although formed from a bicarpelate ovary, the olive fruit has a typical drupe structure consisting of internal stony endocarp or pit, fleshy mesocarp, and external exocarp (King, 1938). In drupes, the

Received for publication 21 July 2003. Accepted for publication 15 Sept. 2003. This work was supported by project CAO98-014 of the Spanish Ministry of Science and Technology Program for the improvement of Quality and Production of Olive Oil and Integrated Action Italy-Spain 2001-0222. G. Costagli was the recipient of a scholarship from the International Olive Oil Council. We thank Rolando Guerriero for the supply of plants and A. de Haro for the use of the nuclear magnetic resonance analyzer.

${ }^{1}$ Corresponding author; email ag2rapop@uco.es.

${ }^{2}$ Also with Dept. di Coltivazione e Difesa delle Specie Legnose, University of Pisa, Via del Borghetto 80, 56124 Pisa, Italy. majority of mesocarp cells are produced by the end of endocarp sclerification, and the bulk of cell expansion occurs after that time (Bollard, 1970). A general perception derived from those patterns is that cell division is the controlling process during the early stages of fruit growth and cell expansion dominates after pit hardening. In the olive it has been hypothesized that water deficit during early fruit development reduces fruit size by decreasing cell division, whereas during later growth it reduces cell expansion (Beede and Goldhamer, 1994; Orgaz and Fereres, 1999).

Recent work on olive indicates that mesocarp cell division and expansion are both highly active through 8 to 10 weeks after full bloom (AFB) (Rallo and Rapoport, 2001; Rapoport, 1999), the time when endocarp expansion is virtually completed (Lavee, 1986; Rallo and Rapoport, 2001). From that time until fruit maturity, considerable cell expansion takes place, and an additional $10 \%$ to $40 \%$ of mesocarp cells may still be produced, depending on the cultivar (Manrique et al., 1999; Rapoport et al., in press). Thus, water deficit occurring at different times during olive fruit development might affect either or both cellular processes. Field comparisons of fruit mesocarp development for irrigated and rainfed olive trees indicated greater cell size for the irrigated treatment at both 8 and 21 weeks after bloom, but no significant effect on cell number (Costagli et al., 2003).

The objective of the present study was to determine the effect of withholding water from young olive plants during early fruit development, on fruit growth and morphogenesis. We specifically addressed how water deficit between 4 and 9 weeks AFB affected mesocarp cell size, mesocarp cell number and size of the endocarp and mesocarp tissues of young and mature fruit. Since in field studies it may be difficult to control the timing and level of water deficit due to slow soil water depletion, carryover effects caused by residual soil moisture, and changing environmental conditions, a greenhouse study was carried out using plants grown in containers. 


\section{Materials and Methods}

Plant material and experimental conditions. Three-yearold Olea europaea L. plants were obtained from rooted cuttings and grown in 2-L pots in a mixture of 1 soil : 1 perlite : 1 peat. All the plants belonged to a highly productive and partially incompatible clone of the cultivar Leccino (Bartolini and Guerriero, 1995). In April 2000, uniform plants were selected and transferred to a greenhouse, where they were irrigated and fertilized with $200 \mathrm{~mL} /$ plant half-strength Hoagland's solution every two weeks. Full bloom, the time at which $50 \%$ of the flowers were open, occurred on 15 May 2000. Due to the lack of wind in the greenhouse, pollination was aided with a brush. At 3 weeks AFB, following initial fruit set and ovary expansion, six plants were assigned to each of two irrigation treatments on the basis of fruit number, in order to achieve similar crop loads per treatment. The average number of fruit per plant was 38 for both treatments at the beginning of the water deficit period (4 weeks AFB). At 22 weeks AFB, the time of final harvest, the average number of fruit per plant was 28 and 26 for fully irrigated and water deficit treatments, respectively. Apart from the destructive sampling, fruit drop after 4 weeks AFB was $11.8 \%$ for the irrigated and $17.1 \%$ for the water deficit treatment.

Tinytag dataloggers (Gemini data loggers Ltd., U.K.) recorded temperature and humidity at half-hour intervals throughout the experiment. Average temperature was $24.7^{\circ} \mathrm{C}$ and relative humidity was $64.4 \%$ during the study period. To reduce temperature, a shading net was placed over the greenhouse from 19 June to 9 Sept. As a consequence, the photosynthetic photon flux at plant level was reduced from about 600 to $300 \mu \mathrm{mol} \cdot \mathrm{m}^{-2} \cdot \mathrm{s}^{-1}$.

IRRIGATION TREATMENTS AND LEAF WATER POTENTIAL. The tWo treatments were a) water deficit during early fruit growth followed by full irrigation, and b) full irrigation throughout fruit growth. In June, plant weight loss at the beginning and the end of the daylight period was measured to quantify plant evapotranspiration. The irrigated treatment received 200 to $400 \mathrm{~mL}$ water per plant every 2 to $4 \mathrm{~d}$, depending on evapotranspirative loss. For the water deficit treatment, water supply was reduced to $50 \%$ evapotranspiration from 13 June to 17 July, 4 to 9 weeks AFB, respectively. The timing and degree of the imposed deficit were chosen in order to affect plant water status for a relatively long period, yet minimize the probability of sudden dehydration due to the small soil volume available to the plants. Following the deficit period, all plants received water equal to the evapotranspirative demand.

Plant water status was assessed by predawn leaf water potential measurements at 6, 8, 11, and 17 weeks AFB, using a custom-built Scholander-type pressure chamber (Tecnogas, Pisa, Italy). One fully expanded leaf per plant from fruiting shoots was sampled for half of the plants at 6 weeks and all plants on the other dates. Leaves were excised with a sharp blade and then immediately put in the chamber cylinder humidified with wet paper towel. The chamber was pressurized with nitrogen gas at a maximum rate of $0.02 \mathrm{MPa} \cdot \mathrm{s}^{-1}$, until sap appeared on at least $50 \%$ of the cut surface of the petiole (Gucci et. al., 1997).

At 6 and 8 weeks AFB, the degree of water deficit was also determined by measuring gas exchange parameters using a portable infrared gas exchange unit (Ciras1, PPSystems, Hoddesdon, U.K.). The flow rate of air entering the leaf cuvette was set at $2.5 \mathrm{~mL} \cdot \mathrm{s}^{-1}$. One or two leaves per plant were measured outdoors at photosynthetic photon flux higher than $800 \mu \mathrm{mol} \cdot \mathrm{m}^{-2} \cdot \mathrm{s}^{-1}$ and ambient $\mathrm{CO}_{2}$ ranging from 330 and $360 \mu \mathrm{L} \cdot \mathrm{L}^{-1}$.

Fruit Growth. At 6, 8, and 22 weeks AFB, fruit were sampled for fresh weight and volume determinations, and then fixed for anatomical studies. The 6- and 8-week dates were chosen to represent critical times during early fruit growth (Manrique et al., 1999). Twenty-two weeks were considered to be the time of early fruit maturation, indicated by color change. At 6 weeks AFB the fresh weight and volume of three fruit per plant from three plants per treatment (half of the plants) were measured, whereas at 8 and 22 weeks AFB four fruit per plant for six plants per treatment (all plants) were used. In addition to the sampled fruit, the volumes of four selected fruit per plant were measured nondestructively every $10 \mathrm{~d}$, during 9 to 20 weeks AFB. Fruit volume was determined by liquid displacement using a graduated cylinder.

At the end of the experiment, after sampling fruit for volume, weight and anatomical studies, four additional fruit were sampled for oil content. Each fruit was weighed and the pit was removed. Then, the fresh and dry weights of the mesocarp were measured. Oil content of two dry mesocarp samples of 0.8 to $1.3 \mathrm{~g}$ from each plant was determined by nuclear magnetic resonance analyzer (model 4000; Oxford Analytical Instruments Ltd., Oxford, U.K.) using the method reported by Del Rio et al. (1993).

Fruit anatomy. Following the determinations of volume and fresh weight, the sampled fruit were fixed in FAE (2 formalin : 1 acetic acid : 17 ethanol (60\%) by volume). Structural observations and measurements were performed on transverse sections at the point of widest fruit diameter, as described by Costagli et al. (2003). The fixed fruit were processed according to standard paraffin procedures (Jensen, 1962), sectioned at 10 to $12 \mu \mathrm{m}$, and stained with toluidine blue O (Sakai, 1973). At 6 and 8 weeks $\mathrm{AFB}, 3$ to $4 \mathrm{~mm}$ equatorial slices of the entire fruit were used. At 22 weeks, it was necessary to first remove the hardened endocarp from the fruit and to section equatorial portions of only mesocarp tissue.

Quantitative observations of tissue growth and differentiation were made with an image analysis system (Leica QWIN 5001; Leica Imaging Systems Ltd., Cambridge, U.K.) connected to either a stereomicroscope or optical microscope. For the 6 and 8 weeks AFB samples, total fruit and endocarp cross-sectional areas of the histological preparations were measured with the stereo microscope, and mesocarp area was calculated as the difference between those two tissues. For the mature, pitted fruit, caliper measurements of the pit diameter were used to calculate endocarp area, assuming a circular shape. Then, mesocarp area was determined by subtracting the calculated endocarp area for each fruit from the total fruit area measured in the preparations.

For each fruit, a field of 150 mesocarp cells was counted and its area determined with the ocular microscope. Those data were used to determine average cross-sectional area per cell, and in combination with mesocarp area to calculate total mesocarp cell number in the transverse sections.

StatistiCal analysis. Data were treated by analysis of variance (ANOVA) for a completely randomized design. Each treatment consisted of six replicate plants. Treatment means were separated within each sampling date by least significant differences. The relationships between fruit variables and leaf water potential were analyzed by linear regression using Sigmaplot (Jaendel Scientific, San Rafael, Calif.) software.

\section{Results}

Water deficit applied between 4 and 9 weeks AFB produced a significant decrease in predawn leaf water potential, which reached minimum values of $-3.1 \mathrm{MPa}$ at the end of that period (Fig. 1). The 


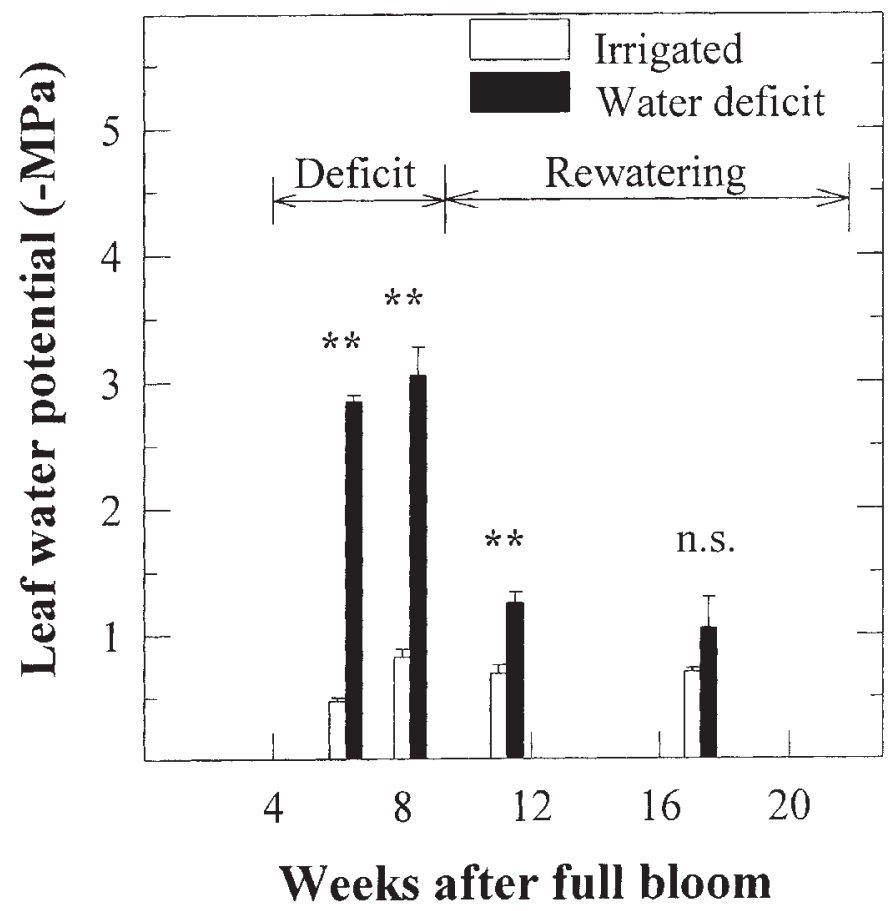

Fig. 1. Predawn leaf water potential of olive plants grown under irrigated or water-deficit conditions in the greenhouse. Water deficit plants received $50 \%$ of evapotranspiration (estimated for fully irrigated plants) between 4 and 9 weeks after full bloom (AFB), after which they were irrigated as the controls. Bars indicate means \pm standard error of three plants per treatment at 6 and 17 weeks AFB or six plants at 8 and 11 weeks AFB. Asterisks (**) indicate significant differences within each date of measurement at $P<0.01$ (LSD test); ssnonsignificant.

difference in predawn leaf water potential between treatments was reduced, but still significant, at the 11-week measurement, 2 weeks after the commencement of rewatering. The ratio between leaf carbon assimilation of water-deficit and irrigated plants was 0.35 and 0.50 at 6 and 8 weeks AFB, respectively (data not shown).

The applied deficit reduced fruit fresh weight and volume at all sampling times, i.e., 6,8 , and 22 weeks AFB, although differences between treatments were not significant at 6 weeks AFB, probably due to low replicate number. The reduction in fresh weight and volume caused by water deficit was proportionally less at 22 than at 8 weeks AFB (Fig. 2). Fruit growth between 9 and 20 weeks $\mathrm{AFB}$, as indicated by nondestructive volume measurements, was almost linear for irrigated plants, whereas it resembled a double sigmoid pattern for the water deficit treatment (Fig. 3). Water deficit decreased the fresh weight, but did not significantly affect the dry weight to fresh weight ratio or the oil content in the mesocarp at 22 weeks AFB (Table 1).

Fruit transverse area of the water deficit treatment was 50,33 and $70 \%$ of the irrigated one at the 6-, 8-, and 22-week sampling dates, respectively. The mesocarp tissue behaved in a similar manner to the fruit, however the endocarp responded differently. Mesocarp growth occurred for both irrigated and water deficit plants between 8 and 22 weeks AFB, but the endocarp of only the water deficit treatment grew during that period. At 22 weeks AFB differences between treatments were significant for mesocarp transverse area, but not for endocarp area. The highly significant differences in endocarp area between treatments at 8 weeks AFB had disappeared at 22 weeks AFB (Fig. 4). Differences between treatments were not significant for all three variables (fruit, mesocarp and endocarp area) at 6 weeks AFB (Fig. 4).

Mesocarp cell size, indicated by area, was significantly dif-

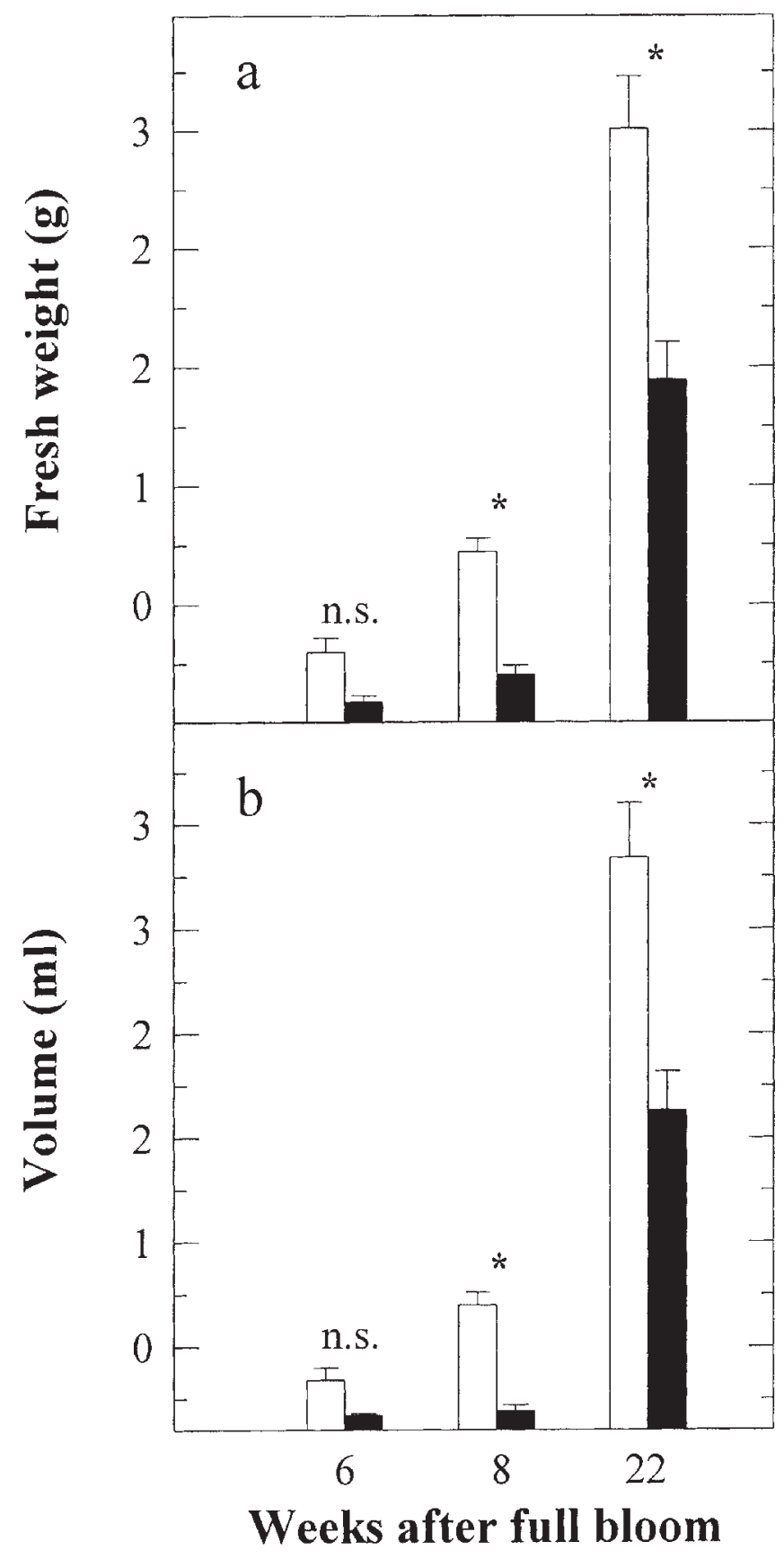

Fig. 2. Fruit fresh weight (a) and volume (b) of irrigated (empty bars) or water deficit (filled bars) olive plants at 6,8, and 22 weeks after full bloom (AFB). Water deficit was applied between 4 and 9 weeks AFB. Bars are means + standard error of six replicates ( 3 at 6 weeks AFB). Asterisks (*) indicate significant differences within each date of measurement at $P<0.05$ (LSD test); snonsignificant.

Table 1. Fruit fresh weight, dry weight to fresh weight ratio and oil content of the mesocarp in irrigated and water deficit olive plants at 22 weeks after full bloom (AFB). Water deficit was applied 4 to 9 weeks AFB. Values are means \pm standard error of four fruits per plant and five replicate plants per treatment. Oil content was measured on bulk mesocarp samples from each plant.

\begin{tabular}{lccc}
\hline & $\begin{array}{c}\text { Fresh wt } \\
\text { (g/fruit) }\end{array}$ & $\begin{array}{c}\text { Dry wt/ } \\
\text { fresh wt } \\
\text { mesocarp }\end{array}$ & $\begin{array}{c}\text { Oil content } \\
\text { (\% of dry wt) }\end{array}$ \\
\hline Treatment & $2.25 \pm 0.22$ & $0.238 \pm 0.016$ & $48.87 \pm 2.77$ \\
Water deficit & $1.13 \pm 0.16$ & $0.265 \pm 0.029 \mathrm{z}$ & $42.61 \pm 4.84$ \\
\hline
\end{tabular}

${ }^{2}$ Mean \pm standard error of three plants. 


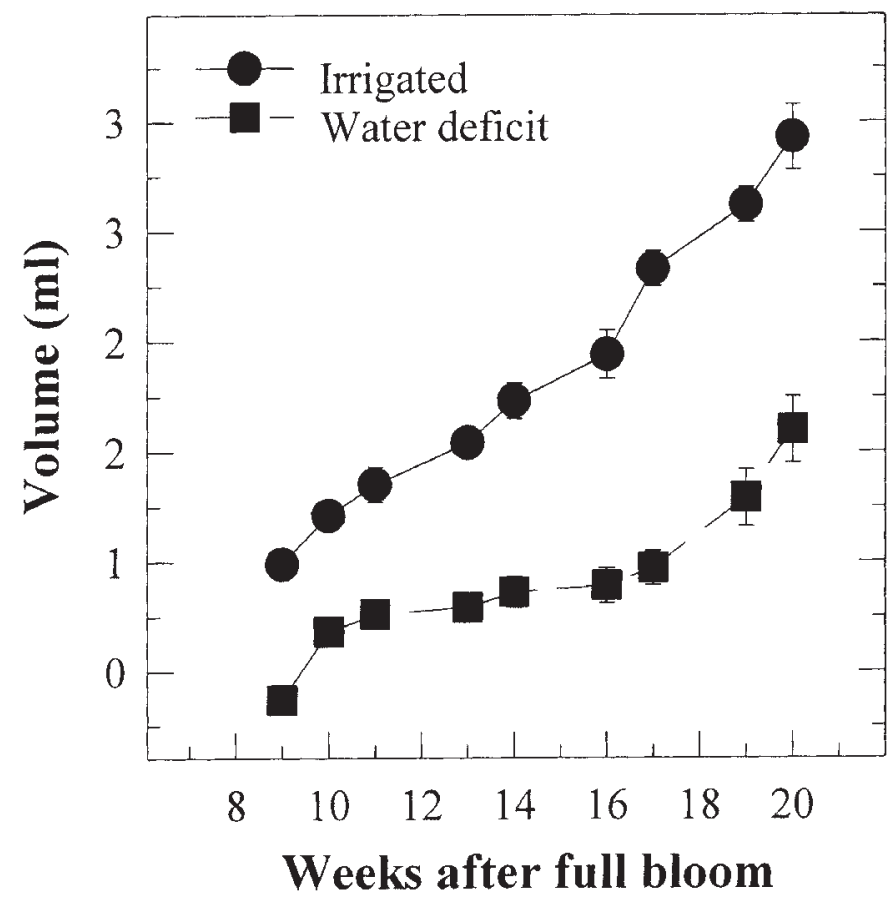

Fig. 3. Fruit growth, assessed by nondestructive volume measurements of the same four fruit per plant, of four olive plants grown under irrigated or water-deficit conditions. Water deficit was applied between 4 and 9 weeks after full bloom (AFB). Symbols are means \pm standard error of four replications.

ferent between treatments at 8 and 22 weeks AFB. However, the mesocarp cell number was similar for both treatments at all times. Most mesocarp cells, $87 \%$ of those at 22 weeks AFB, had already been produced by 6 weeks AFB for both treatments (Fig. 5).

At 8 weeks AFB, both the mesocarp and endocarp areas were highly correlated with predawn leaf water potential (Fig. 6), as was the mesocarp cell area (Fig. 7). There was no correlation, however, between mesocarp cell number and predawn leaf water potential (Fig. 7).

The degree of growth of each tissue or cellular parameter occurring at different times during fruit development can be expressed by dividing its final value into the percentage increments achieved over the different time intervals (Fig. 8). For the irrigated plants, $<1 \%$ of the mesocarp was present in the ovary at bloom, $12 \%$ and $26 \%$ of mesocarp final size were accomplished by $6 \%$, and 8 weeks AFB, respectively, and $74 \%$ of growth occurred between 8 and 22 weeks AFB. In the deficit treatment mesocarp growth was shifted towards later in development, so a higher proportion of mesocarp growth $(84 \%)$ occurred in the final period. The growth of endocarp area showed a considerable shift in timing in response to the early water deficit. Ninety percent of endocarp growth had occurred by 8 weeks AFB in the irrigated treatment, but only $40 \%$ when the deficit irrigation treatment was imposed (Fig. 8). Individual cells in the mesocarp followed the same expansion pattern as did the whole tissue. Water deficit slightly decreased the proportion of cell numbers produced between 6 and 8 weeks AFB, and increased the proportion of cell numbers produced between 8 and 22 weeks AFB.

\section{Discussion}

When water deficit applied during early fruit growth reduced fruit size, the mesocarp and the endocarp responded in different ways, indicating both competition and interactions between the

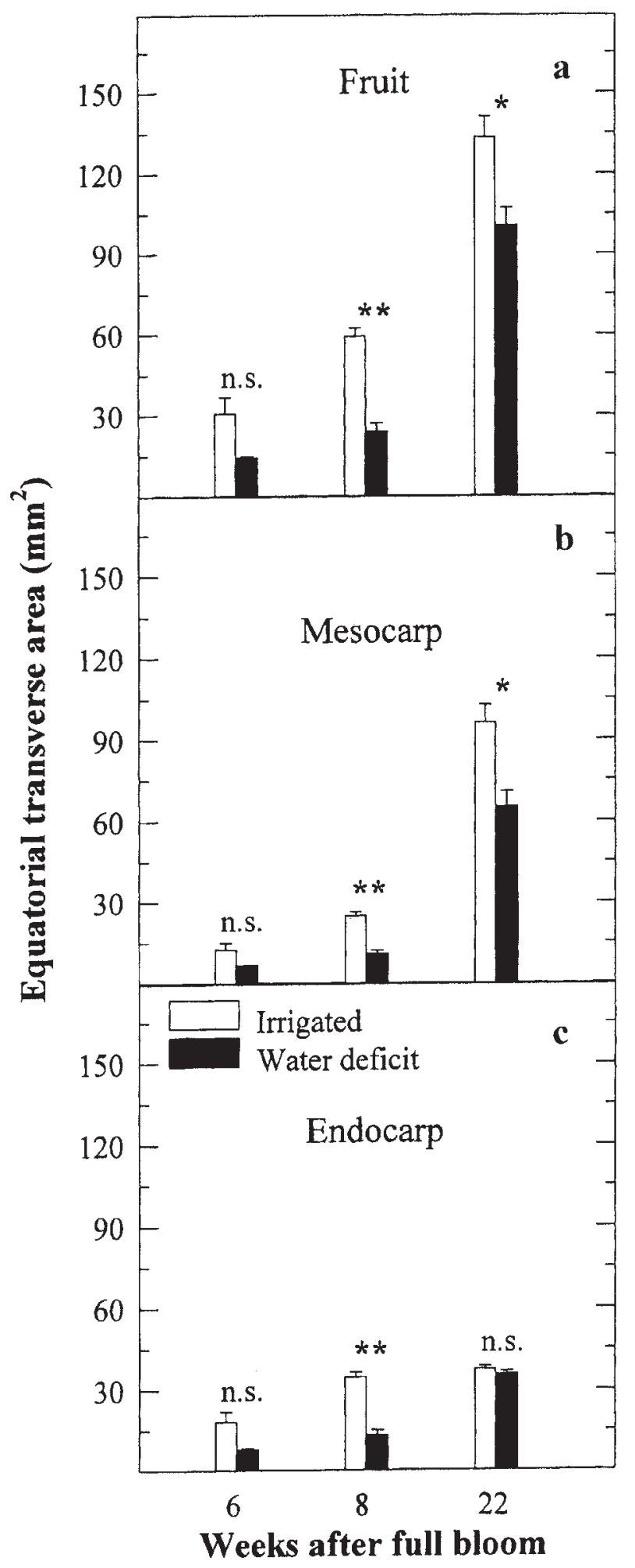

Fig. 4. Area of fruit (a), mesocarp (b) and endocarp (c) measured on transverse equatorial sections from fully irrigated or water-deficit olive plants 6,8 , and 22 weeks after full bloom (AFB). Water deficit was applied between 4 and 9 weeks AFB. Bars represent means \pm standard error of six replicate plants (3 at 6 weeks AFB). Four fruit per plant were measured ( 3 at 6 weeks AFB). Asterisks indicate significant differences within each date of measurement at $P<0.05$ (*) or $0.01(* *)$ (LSD test); Nsnonsignificant..

developing fruit tissues. Water deficit decreased the equatorial transverse area for both tissues in fruit sampled at 8 weeks AFB, i.e., during the stress period, but only reduced the area of the 


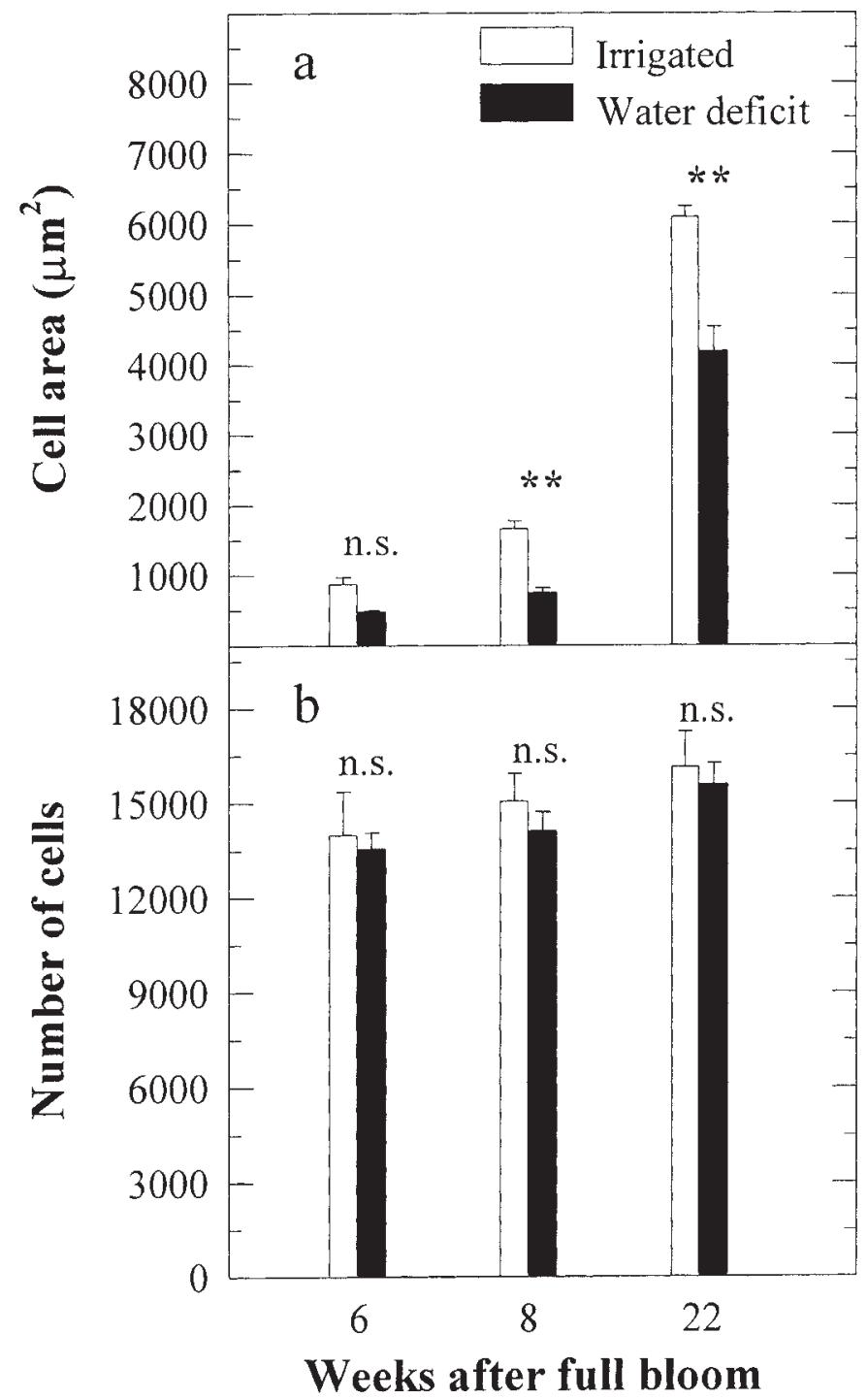

Fig. 5. Mesocarp cell area (a) and mesocarp cell number (b) measured on equatorial transverse sections of fruit from irrigated or water deficit olive plants 6,8 , and 22 weeks after full bloom. Experimental conditions and symbols as in Fig. 4.

mesocarp in those sampled at 22 weeks AFB, i.e., 13 weeks after the resumption of irrigation. During the period of rewatering, between 9 and 22 weeks AFB, the endocarp of previously stressed plants reached the size of continuously irrigated plants, while the mesocarp recovered only partially (Fig. 4), implying that endocarp growth had a higher priority than mesocarp growth to recover once stress was relieved. Continued endocarp growth after 8 weeks AFB in the water deficit treatment indicates that sclerification was still progressing, since only the still unsclerified parenchyma cells can expand that tissue (King, 1938). The slowing down of fruit growth in the deficit treatment shown by the continuous volume measurements (Fig. 3) might have also been due to the extended period of endocarp growth and sclerification, during which little growth occurred in the mesocarp.

Fruit fresh weight, volume and area were reduced in the water deficit treatment, but partial fruit growth recovery after the resumption of full irrigation is indicated by the lower relative differences between treatments for those variables at 22 than at 8 weeks AFB (Figs. 2 and 4), and by the similarity in fruit volume increase after 17 weeks AFB (Fig.3). Reduced water uptake by the root, and higher resistance in the stem and root hydraulic

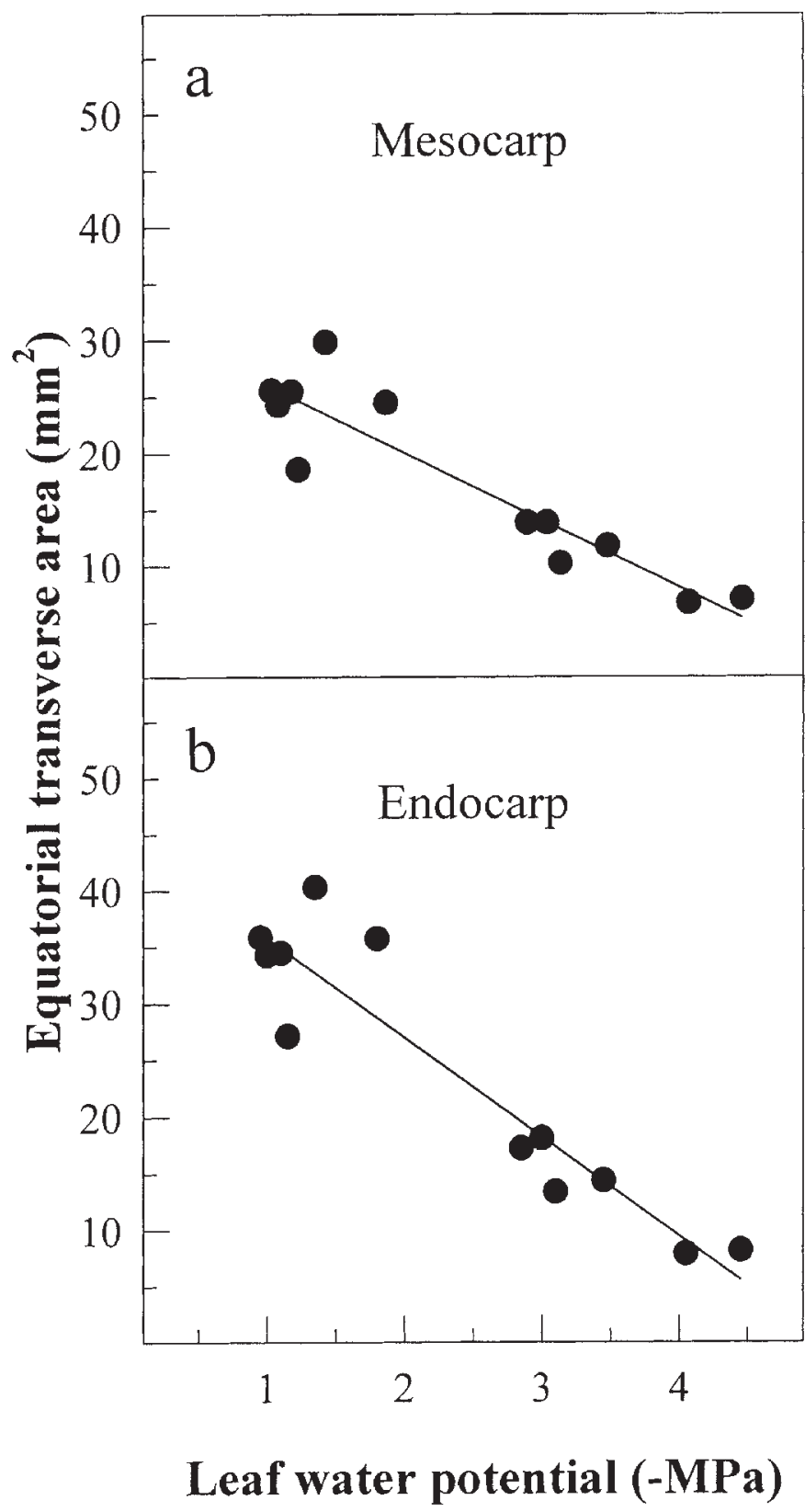

Fig. 6. The relationship between mesocarp (a) or endocarp (b) area, (transverse equatorial sections), and predawn leaf water potential of both irrigated and waterdeficit olive plants measured 8 weeks after full bloom (AFB). Two leaves and four fruit were measured per plant; each symbol represents average values for one plant. Regression equations: $\mathrm{y}=-5.831 \mathrm{x}+31.384 ; R^{2}=0.85$ (mesocarp); $\mathrm{y}=-8.762 \mathrm{x}+44.551 ; R^{2}=0.88$ (endocarp).

pathway of plants that had experienced a period of water deficit might have been partially responsible for the lack of complete recovery of leaf water potential at 11 weeks AFB (Fig. 1), 2 weeks after irrigation was resumed. However, even if leaf water potential was lower for the water deficit plants at 11 weeks AFB, there was still a long recovery period during which leaf water potential was similar for both treatments, but fruit growth did not fully recover.

Within the mesocarp, which was reduced by the early water deficit, cell size was reduced, but cell number was not. This contradicts what has been previously assumed (Beede and Goldhamer, 1994; Orgaz and Fereres, 1999) and implies that cell expansion was more sensitive to water deficit than cell division, even in the 


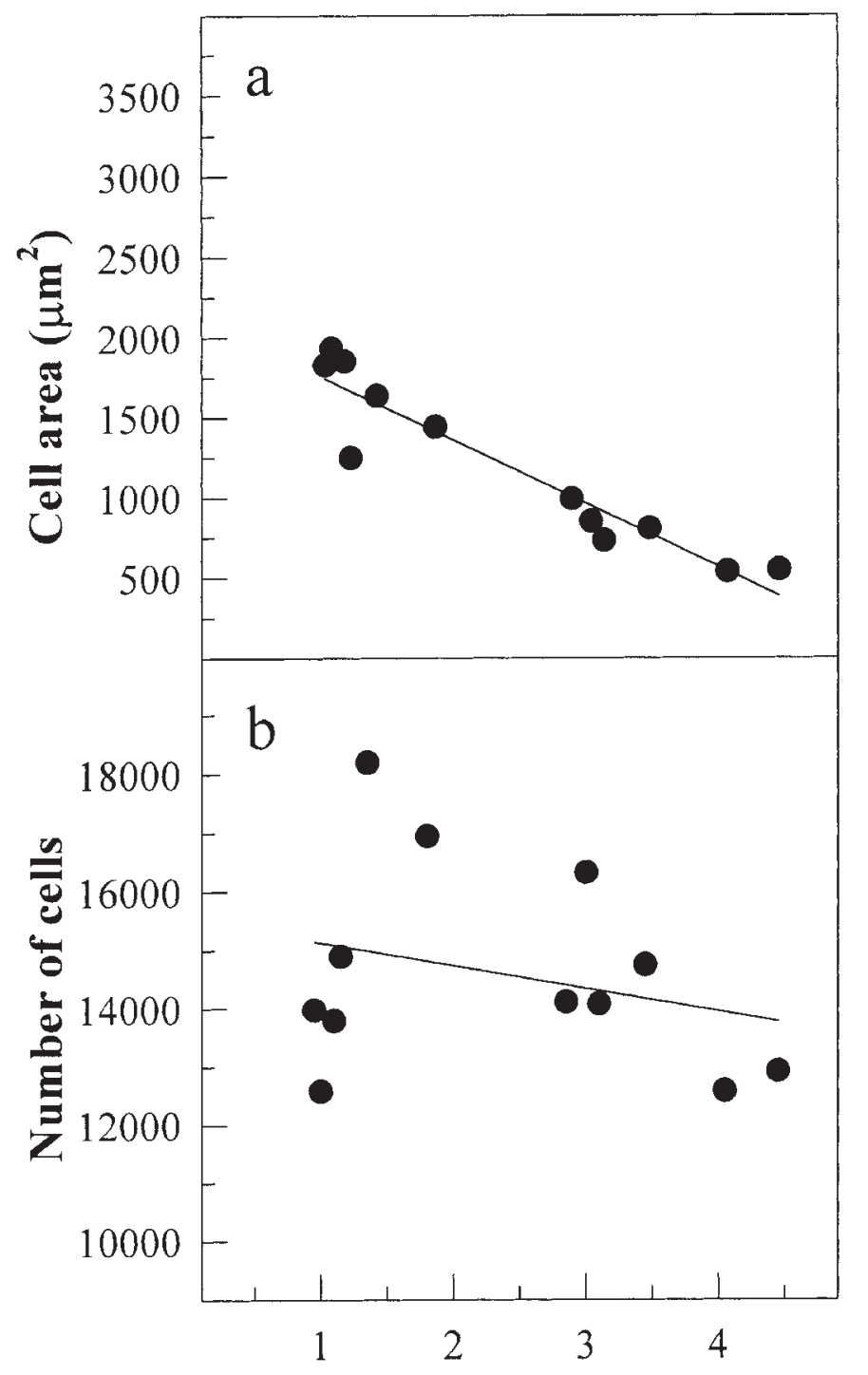

Leaf water potential (-MPa)

Fig. 7. The relationship between mesocarp cell transverse area (a) or cell number (b), and predawn leaf water potential of both irrigated and water-deficit olive plants 8 weeks after full bloom (AFB). Two leaves and four fruit were measured per plant; each symbol represents average values for one plant. Regression equations: $\mathrm{y}=-388.5 \mathrm{x}+2114.5 ; R^{2}=0.89$ (cell area); $\mathrm{y}=-390.7 \mathrm{x}+15515.3$; $R^{2}=0.08$ (number of cells).

early stages of fruit growth when cell division is highly active (Rallo and Rapoport, 2001; Rapoport, 1999). These results also demonstrated that water deficit development early during fruit formation affects cell size not only at the end of the stress period, but also at maturity. In potted pear trees (Pyrus communis L.) Marsal et al. (2000) found a significant correlation between the degree of water deficit (between 34 and $63 \mathrm{~d}$ AFB) and fruit cell area index at the end of the stress period, but not at harvest. Moreover, there were no differences in cell number along the radius between irrigated and deficit treatments (Marsal et al., 2000).

The degree and timing of mesocarp cell size reduction due to water deficit corresponded with those of mesocarp tissue area reduction (Figs. 4, 5, and 8). In other words, mesocarp tissue area and mesocarp cell area followed similar patterns in each treatment. Those parallel growth patterns, as well as the

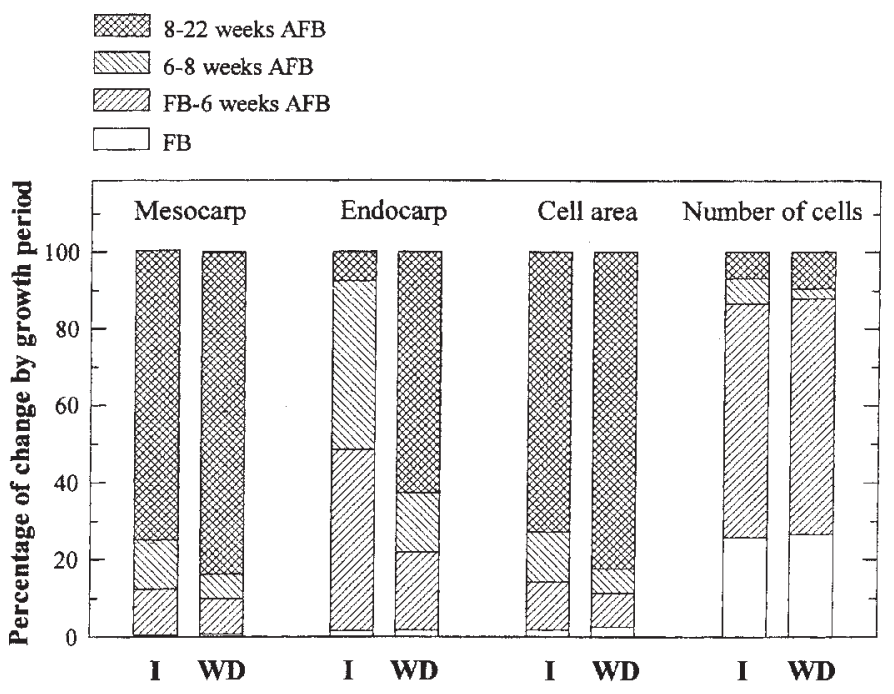

Fig. 8. Percentage of change of mesocarp area, endocarp area, mesocarp cell area, and mesocarp cell number of fruit from irrigated (I) or water deficit (WD) olive plants during different time intervals. Intervals were full bloom (FB), FB to 6 weeks after FB (AFB), 6 to 8 weeks AFB, 8 to 22 weeks AFB. Values were calculated within each treatment as a percentage of final values at 22 weeks AFB.

considerable increase in cell size during fruit development, are further evidence that cell expansion is a major driving force throughout fruit growth, and not just during the final period. However, a restricted capacity for post-stress cell wall expansion does not seem to be responsible for reduced mesocarp size and mesocarp cell size in the water deficit treatment, as the cell area increase from 8 to 22 weeks AFB was relatively greater for the water deficit plants (eight times) than for the control (six times) (Fig. 2).

No mesocarp cell number differences between treatments were found in the current study, nor in field irrigation experiments (Costagli et al., 2003). However, differences in cell number, both at 8 weeks AFB and fruit maturity, have been positively correlated with fruit size differences between olive cultivars (Rapoport, et al., in press). Varietal differences in fruit cell number have also been observed in strawberry, Fragaria vesca (Cheng and Breen, 1992), apple, Malus domestica Borkh. (Smith, 1950), peach, Prunus persica (Scorza et al., 1991), and saskatoon, Amelanchier alnifolia (McGarry et al., 2001).

One of the reasons why we found no differences in cell number between treatments in this study could have been that water deficit was imposed from 4 weeks AFB, whereas Rallo and Rapoport (2001) showed that the number of cells increased to a greater extent prior to that time, during the first 4 weeks AFB. Another possibility was that the degree of water deficit achieved was not severe enough to affect cell division, since the olive plant is relatively tolerant to drought stress. Nonetheless, the maximum degree of stress that we imposed (about $-3 \mathrm{MPa}$ ) was not light since it exceeded the turgor loss point for adult olive trees (Lo Gullo and Salleo, 1988). Other factors to consider when trying to resolve whether cell division might have been affected by water deficit early in fruit development are that a) cell number was a calculated parameter derived from mesocarp area and cell size, and b) as both processes occur simultaneously, if expansion is more active than division, then the effect on the latter may have been masked entirely or partially.

In conclusion, this study shows the complexity of the interaction between plant water status and fruit cell and tissue morphoge- 
netic processes in determining final fruit size and the potential for growth recovery after stress. An early period of water deficit reduced cell size but not cell number in the mesocarp. Furthermore, when the stress was relieved, endocarp growth recovered more than mesocarp growth, which indicates that the endocarp is not only metabolically expensive, but also a preferred sink tissue during some stages of olive fruit development.

\section{Literature Cited}

Bartolini, S. and R. Guerriero. 1995. Self-compatibility in several clones of olive oil cultivar 'Leccino'. Adv. Hort. Sci. 9:71-74.

Beede, R. H. and D. Goldhamer. 1994. Olive irrigation management, p. 6168. In: L. Ferguson, G.S. Sibbett, and G.C. Martin(eds.). Olive Production manual. Univ. Calif. Div. Agr. Natrl. Resour., Oakland, Publ. 3353.

Behboudian, M.H. and T.M. Mills, 1997. Deficit irrigation in deciduous orchards. Hort. Rev. 21:105-131.

Bollard, E.G. 1970. The physiology and nutrition of developing fruits, p. 387-425. In: A.C. Hulme (ed.). The biochemistry of fruits and their products. vol. 1. Academic Press, New York.

Bongi, G. and A. Palliotti. 1994. Olive, p.165-187. In: B. Schaffer and P.C. Anderson (eds.). Handbook of environmental physiology of fruit crops. CRC Press, Boca Raton, Fla.

Cheng, G.W. and P.J. Breen. 1992. Cell count and cell size in relation to fruit size among strawberry cultivars. J. Amer. Soc. Hort. Sci. 117: 946-950.

Costagli, G., R. Gucci, and H.F. Rapoport. 2003. Growth and development of fruits of olive 'Frantoio' under irrigated and rainfed conditions. J. Hort. Sci. Biotechnol. 78:119-124.

Del Rio, M., J. Fernandez-Martinez, and A. de Haro. 1993. Wild and cultivated Borago officinalis L.: Sources of gamma-linolenic acid. Grasas y Aceites 44:125-126.

Goldhamer, D.A., J. Dunai, and L.F. Ferguson. 1994. Irrigation requirements of olive trees and responses to sustained deficit irrigation. Acta Hort. 356:172-175.

Gucci, R., L. Lombardini, and M. Tattini. 1997. Analysis of leaf water relations in two olive (Olea europaea) cultivars differing in tolerance to salinity. Tree Physiol. 17:13-21.

Inglese, P., E. Barone, and G. Gullo. 1996. The effect of complementary irrigation on fruit growth, ripening pattern and oil characteristics of olive (Olea europaea L.) cv. Carolea. J. Hort. Sci. 71:257-263.

Jensen, W.A. 1962. Botanical histochemistry. W.H. Freeman and Co., San Francisco, Calif.

King, J.R. 1938. Morphological development of the fruit of the olive.
Hilgardia 11:437-458.

Lavee, S. 1986. Olive, p. 261-76. In: S.P. Monselise (ed.). Handbook of fruit set and development. CRC Press Inc., Boca Raton, Fla.

Lavee, S., M. Nashef, M. Wodner, and H. Harshemesh. 1990. The effect of complementary irrigation added to old olive trees (Olea europaea L.) cv 'Souri' on fruit characteristics, yield and oil production. Adv. Hort. Sci. 4:135-138.

Lo Gullo, M.A. and S. Salleo. 1988. Different strategies of drought resistant in three sclerophyllous trees growing in the same environmental conditions. New Phytol. 108:267-76.

Manrique, T., J. Castro, M. Pastor, and H.F. Rapoport. 1999. Mesocarp cell division and expansion in the growth of olive fruits. Acta Hort. 474:301-304.

Marsal, J., H.F. Rapoport, T. Manrique, and J. Girona. 2000. Pear fruit growth under regulated deficit irrigation in container-grown trees. Scientia Hort. 85:243-259.

McGarry, R., J. Ozga, and D. Reinecke. 2001. Differences in fruit development among large- and small-fruited cultivars of Saskatoon (Amelanchier alnifolia). J. Amer. Soc. Hort. Sci. 126:381-385.

Mitchell, P.D., D.J. Chalmers, P.H. Jerie, and G. Burge. 1986. The use of initial withholding of irrigation and tree spacing to enhance the effect of regulated deficit irrigation on pear trees. J. Amer. Soc. Hort. Sci 111(6):858-861.

Orgaz, F. and E. Fereres. 1999. Riego, p. 269-288. In: D. Barranco, R. Fernández-Escobar, and L. Rallo (eds.). El cultivo del olivo. MundiPrensa, Barcelona, Spain.

Proietti, P. and E. Antognozzi. 1996. Effect of irrigation on fruit quality of table olives (Olea europaea), cultivar 'Ascolana tenera'. N.Z. J. Crop Hort. Sci. 24:175-181.

Rallo, P. and H.F. Rapoport. 2001. Early growth and development of the olive fruit mesocarp. J. Hort. Sci. Biotechnol. 76:408-412.

Rapoport, H. F. 1999. Botánica y morfología, p. 35-60. In: D. Barranco, R. Fernández-Escobar, and L. Rallo (eds.). El cultivo del olivo. MundiPrensa, Barcelona, Spain.

Rapoport, H.F., T. Manrique, and R. Gucci. Cell division and expansion in the olive fruit. XXVI Intl. Hort. Congr., Toronto, August 2002. Acta Hort. (in press).

Sakai W.S. 1973. Simple method for differential staining of paraffin embedded plant material using toluidine blue O. Stain Technol. 48:247-249.

Scorza, R., L.G.May, B. Purnell, and B. Upchurch. 1991. Differences in number and area of mesocarp cells between small- and large-fruited peach cultivars. J. Amer. Soc. Hort. Sci. 116:861-864.

Smith, W.H. 1950. Cell multiplication and cell enlargement in the development of the flesh of the apple fruit. Ann. Bot. 14:23-38. 